\title{
Diagnosis of primary pulmonary T- cell/ histiocyte-rich large B cell lymphoma with tissue eosinophilia via clinicopathological observation and molecular assay
}

Jin Zhu ${ }^{1,2+}$, Yingmei Wang ${ }^{1+}$, Li Gong $^{3}$ and Gaosheng Huang ${ }^{1 *}$

\begin{abstract}
Background: Primary pulmonary lymphoma (PPL) is rare and easily misdiagnosed because of the lack of typical clinical features. It most commonly involves elderly patients aged between 60 and 70 years, and pathological diagnosis depends mainly on chest surgery rather than bronchial mucosal biopsy. Via percutaneous needle aspiration biopsy of the lung of a 33-year-old woman, which had distinct tissue eosinophilia, we diagnosed a rare case of rapidly growing large $B$ cell lymphoma.
\end{abstract}

Methods: Bronchial mucosal biopsy and computed tomography-guided percutaneous needle aspiration biopsy were performed to determine the nature of the lesion, and we identified its immunophenotype using immunohistochemistry. We used BIOMED-2 gene rearrangement PCR to determine lymphocyte clonality; laser microdissection was used to confirm the clonality of suspicious malignant lymphocytes.

Results: Morphologically, the lesion was composed of a large number of eosinophilic cells and a few lymphoid cells. Immunohistochemical staining revealed a few CD1a-positive cells, but they were S-100-negative. The small lymphoid cells predominantly expressed CD3; the large lymphoid cells expressed CD20 and some scattered large lymphoid cells expressed Pax5. However, molecular studies confirmed clonal immunoglobulin heavy chain (IGH)-D gene rearrangement in Pax5-positive large B lymphocytes.

Conclusions: This is the first recorded case of T- cell/histiocyte-rich large B cell lymphoma with tissue eosinophilia of the lung. It highlights the unusual morphological features of PPL that might be mistaken for eosinophilic granuloma or parasitic infection. In addition, IGH and T cell receptor gene rearrangement play important roles in differentiating rare B cell lymphoma from lung space-occupying lesions with abundant eosinophils or T cell infiltration.

Virtual Slides: The virtual slide(s) for this article can be found here: http://med.motic.com/MoticGallery/Slides/ AC5C9A6F-46EC-4C71-A448-1312F6900C65? user=2C69F0D6-A478-4A2B-ABF0-BB36763E8025

Keywords: Primary pulmonary lymphoma, B cell lymphoma, Tissue eosinophilia, Gene rearrangement

\footnotetext{
* Correspondence: huanggs@fmmu.edu.cn

${ }^{\dagger}$ Equal contributors

'The State Key Laboratory of Cancer Biology, Department of Pathology, Xijing Hospital, Fourth Military Medical University, Changle West Road \#169, Xi'an 710032, People's Republic of China

Full list of author information is available at the end of the article
} 


\section{Background}

Primary pulmonary lymphoma (PPL) is defined as a clonal lymphoid proliferation affecting one or both lungs in a patient with no detectable extrapulmonary involvement at diagnosis. It is a rare entity, representing less than $1 \%$ of primary pulmonary malignancies and accounting for 4-11\% of extranodal lymphomas [1-3]. Due to its atypical clinical manifestation and complicated imaging features, PPL is easily misdiagnosed and incorrectly treated. Historically, PPL diagnosis mainly depends on chest surgery to obtain pathological evidence, and most cases cannot be diagnosed only by bronchial mucosal biopsy $[4,5]$. We describe a case of primary pulmonary large B cell lymphoma with marked tissue eosinophilia and increased $\mathrm{T}$ cells in which histological, immunohistochemical, and gene rearrangement findings were combined to obtain a diagnosis by computed tomography (CT)-guided percutaneous needle aspiration biopsy.

\section{Case presentation}

\section{Clinical history}

A 33-year-old woman had cough and expectoration without fever or other discomfort. A peripheral blood count revealed an increased white cell count, but there was no obvious abnormal change on chest radiographs. Thus, the local physician attributed her symptoms to allergic bronchitis and she received anti-inflammatory treatment. However, she visited the hospital again after five months because of the same symptoms, which were accompanied by severe shortness of breath. Laboratory examination revealed increased white blood cells in the peripheral blood, but the absolute value of eosinophilic granulocytes was in the normal range. Other tests showed increased erythrocyte sedimentation rate (ESR), negative autoantibody, carcinoembryonic antigen far lower than the reference value, but a weakly positive Postscript Printer Description skin test. Chest radiography and CT scan revealed a space-occupying lesion in the upper lobe of the right lung, which indicated lung cancer with atelectasis of the right upper lung (Figure 1) without nodal involvement. We performed bronchial mucosal biopsy and CT-guided percutaneous needle aspiration biopsy (aspiration biopsy), which revealed extensive eosinophil infiltration and no evidence of malignancy. Positron emission tomography scan and bone marrow biopsy were also normal. Repeated sputum cultures and parasite antigen testing excluded bacterial and parasitic infection, respectively. In addition, we did not find acid-fast bacilli from smears or bronchoalveolar lavage fluid (BALF), and the Mycobacterium tuberculosis (TB) DNA copy number from the BALF and lung biopsy tissues were all $<25$ copies/mL; therefore, we also excluded TB. The lesion was suspected eosinophilic granuloma, and the patient received an experimental glucocorticoid treatment that successfully alleviated her symptoms. However, subsequent CT scans revealed an increased mass, and the patient underwent biopsy again. While her bone marrow biopsy was normal, the ESR remained increased.

\section{Methods}

Immunohistochemistry

Immunohistochemical staining was performed using EnVision $^{\text {TM }}$ Systems (Dako, Glostrup, Denmark) according to the manufacturer's instructions. The primary antibodies used were mouse anti-human antibodies against anaplastic lymphoma kinase (ALK), clusterin, CD34, AE1/AE3, CD30, CD1 $\alpha$, CD20, and CD68, and rabbit anti-human antibodies against S-100, CD3, and Pax5. All reagents were supplied by Dako but CD3 and CD34 was from Maixin Biotechnology Corp. Ltd. (Fuzhou, China).

\section{Laser microdissection}

Ten $10-\mu \mathrm{m}$ tissue sections $\left(1.5 \times 1.5 \mathrm{~cm}^{2}\right)$ were obtained from representative paraffin blocks and placed on an ultraviolet (UV)-absorbing membrane. The sections underwent laser microdissection using an LMD6000 laser microdissection microscope (Leica Microsystems Ltd., Wetzlar, Germany). After immunohistochemical staining, slides were mounted on a microstat, and Pax5-positive lymphoid cells were dissected using a UV laser in motorized optical beam scanning mode. The membrane (with the attached specimen) was dropped into the cap of a $0.5-\mathrm{mL}$ microcentrifuge tube and prepared for DNA extraction. For each dissected lesion, a similar volume of surrounding normal lung tissue was isolated and analyzed as a control.

\section{DNA extraction}

Four $20-\mu \mathrm{m}$ thick sections from formalin-fixed, paraffinembedded (FFPE) tissue blocks obtained by aspiration biopsy were cut into centrifuge tubes. We isolated DNA from microdissection samples or aspiration biopsy samples using the RecoverAll ${ }^{\mathrm{TM}}$ Kit (AM1975; Ambion, Foster City, CA, USA) according to the manufacturer's protocol. Briefly, FFPE tissue samples were deparaffinized with xylene and graded ethanol and then digested with the appropriate volume of lysate buffer ( $40 \mu \mathrm{L}$ for microdissection samples; $100 \mu \mathrm{L}$ for aspiration biopsy samples) and proteinase $\mathrm{K}$ ( $2 \mu \mathrm{L}$ for microdissection samples; $6 \mu \mathrm{L}$ for aspiration biopsy samples) in a water bath $\left(50{ }^{\circ} \mathrm{C}\right)$ for $16 \mathrm{~h}$. We added the appropriate volume of isolation additive/ethanol mixture to each sample and filtered or washed them repeatedly. After RNase digestion and DNA purification, the genomic DNA was extracted and stored at $-20^{\circ} \mathrm{C}$.

\section{BIOMED-2 gene rearrangement analysis}

We evaluated the clonality of $\mathrm{T}$ cell receptor (TCR) and immunoglobulin heavy chain (IGH) genes using the PCR 

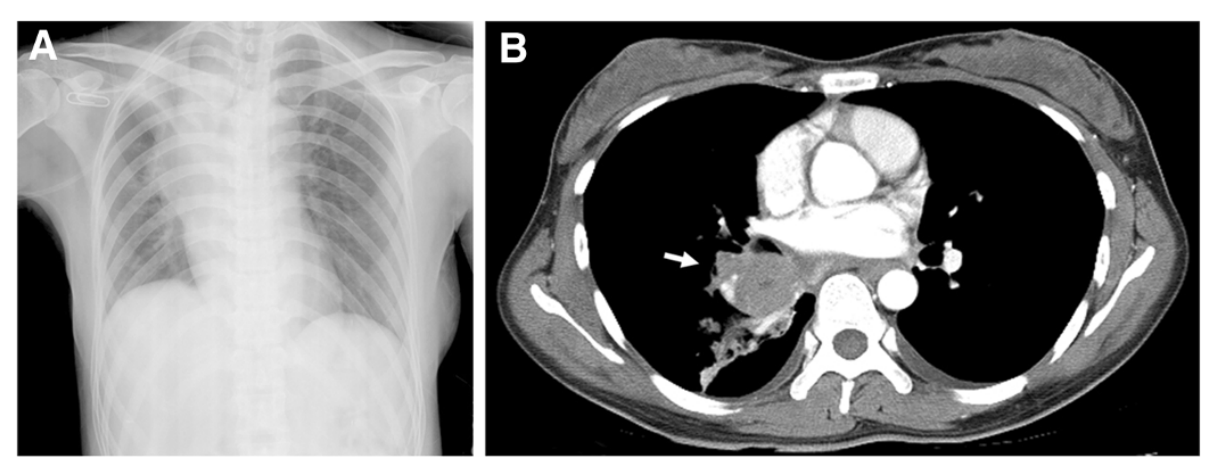

Figure 1 Chest radiograph and lung CT scan. A: Chest radiograph showing widened mediastinum in the upper-middle lobe and upper lobe atelectasis in the right lung, indicating a space-occupying lesion. B: Lung CT scan showing a right hilar mass measuring about $5.0 \times 4.8 \mathrm{~cm}$ (arrow).

technique described by Liu et al. [6]. The reaction conditions were selected for a final volume of $50 \mu \mathrm{L}$ containing 100 ng DNA, $200 \mu \mathrm{M}$ dNTP, 10 pmol each primer irrespective of total numbers of primers in each multiplex PCR tube, $1.5 \mathrm{mM} \mathrm{MgCl}$, and $1 \mathrm{U}$ Taq enzyme. Amplification was performed using an Eppendorf thermal cycler (Eppendorf, Hamburg, Germany) for 35 cycles (denaturation at $94^{\circ} \mathrm{C}$ for $1 \mathrm{~min}$, annealing at $60^{\circ} \mathrm{C}$ for $1 \mathrm{~min}$, extension at $72^{\circ} \mathrm{C}$ for $1 \mathrm{~min}$ ). The PCR products were visualized using polyacrylamide gel electrophoresis.

\section{Results}

\section{Pathological observation}

At the first aspiration biopsy, histopathology revealed numerous eosinophilic cells infiltrating the lesion (Figure 2A-B), and no definite tumor cells were found. Immunohistochemical staining was negative for S-100, ALK, clusterin, CD34, AE1/AE3; there were only a few large CD30-positive and $\mathrm{CD} 1 \alpha$-positive cells (Figure 3A), but more CD68-positive cells (Figure 3B).

Following glucocorticoid treatment, histopathology revealed focal accumulation of lymphocytes and less
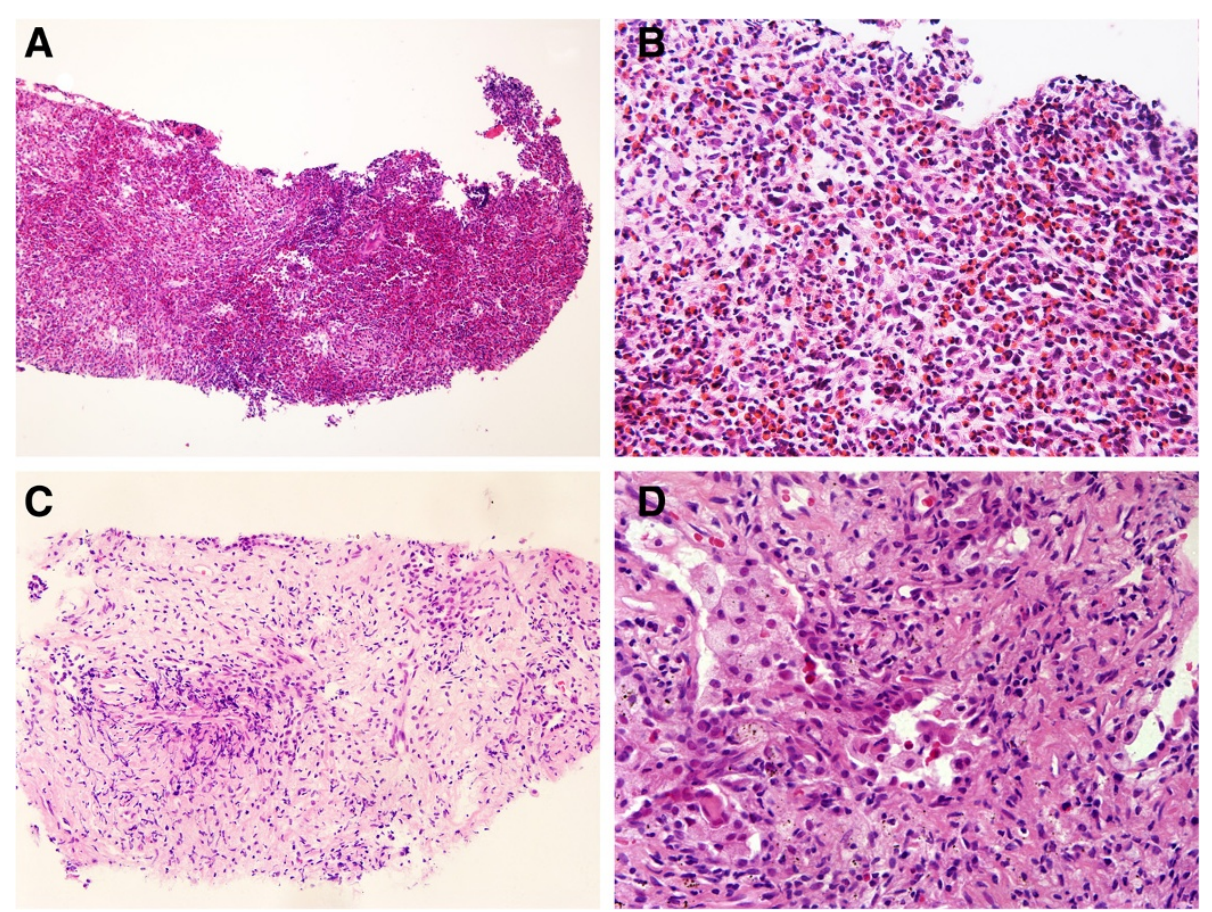

Figure 2 Histopathological characteristics of the lesion. A, B: Hematoxylin-eosin (H\&E)-stained aspiration biopsy section showing marked eosinophilia in the lesion (Figure 2A, ×100; Figure 2B, ×400). C, D: H\&E-stained aspiration biopsy after glucocorticoid treatment showing only a few eosinophils (Figure 2C, ×200; Figure 2D, ×400). 

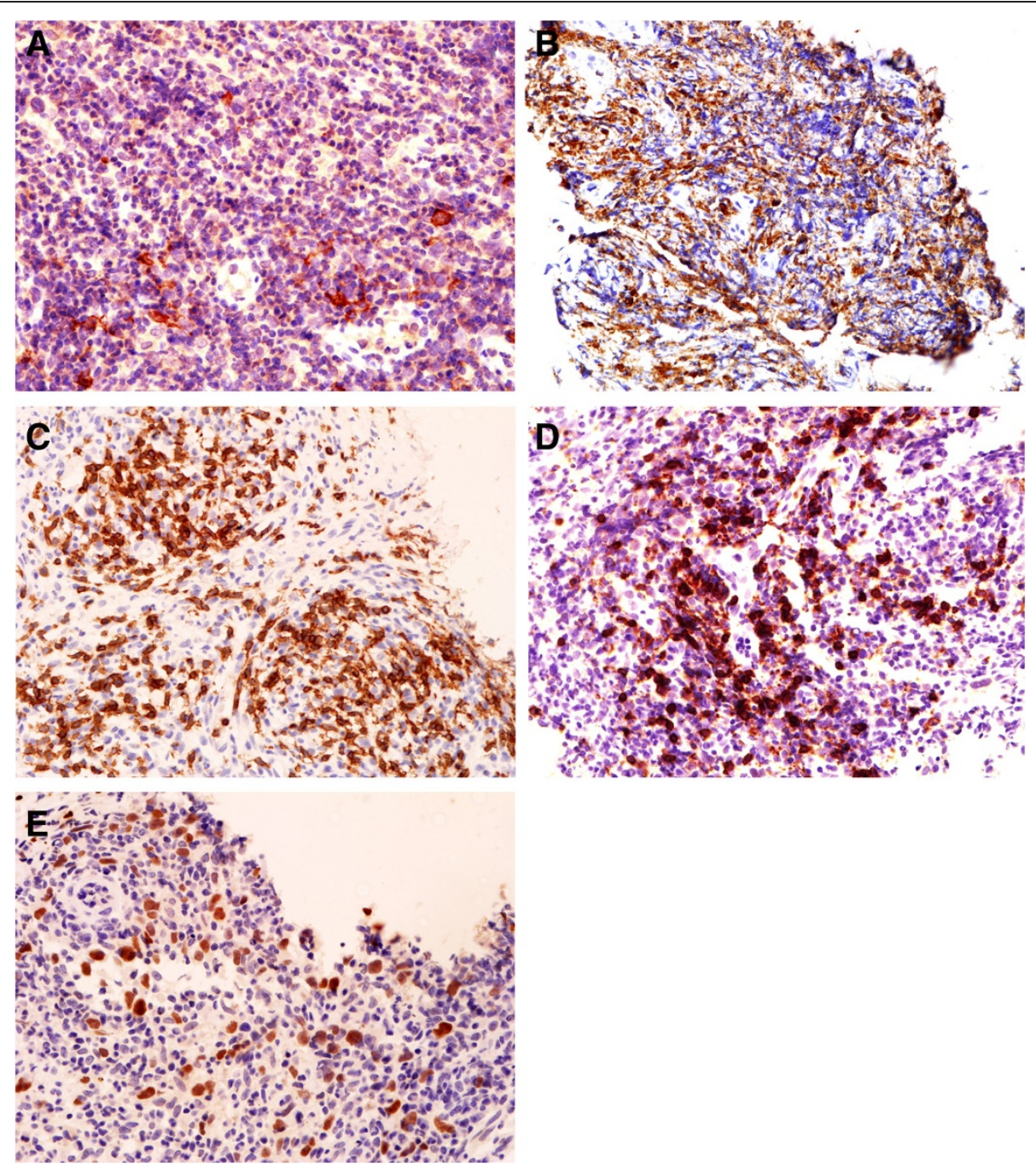

Figure 3 Immunohistochemical features of the lesion. A: Immunohistochemical CD1a staining showing only a few CD1a-positive cells ( $\times 400)$. B: Immunohistochemical CD68 staining revealing a diffused pattern of CD68-positive cells $(\times 400)$. C: Immunohistochemical CD3 staining revealing a predominant nodular pattern of CD3-positive cells ( $\times 400)$. D: Immunohistochemical CD20 staining revealed that many large lymphoid cells were positive. E: Immunohistochemical Pax5 staining showing scattered, Pax5-positive large B cells $(\times 400)$.

eosinophil infiltration (Figure 2C-D). Immunohistochemical staining showed that the background small lymphocytes predominantly expressed CD3 (Figure 3C), while many large lymphoid cells strongly expressed CD20 (Figure 3D) and some large lymphocytes expressed Pax5 (Figure 3E), and their average nuclei diameter was approximately $11 \mu \mathrm{m}$. The distribution of Ki67-positive cells was not even, but most of the cells were scattered larger cells.

\section{Gene rearrangement}

Gene rearrangement analysis of the lung biopsy tissue revealed rearrangement of clonal IGH genes, including IGH-D and IG kappa (K)-B, and no clonal rearrangement of TCR genes (Figure 4). Laser capture microdissection determined that the IGH-D gene rearrangement (Figure 5) mainly occurred in Pax5-positive large B lymphocytes.

\section{Diagnosis and outcome}

Based on the histopathological characteristics, immunohistochemical features, and gene rearrangement analysis, we eventually diagnosed the patient with primary pulmonary T- cell/histiocyte-rich large B cell lymphoma with tissue eosinophilia. Subsequently, she completed three cycles of chemotherapy dominated by the cyclophosphamide, doxorubicin, vincristine, and prednisone $(\mathrm{CHOP})$ or CHOP-like regimen. CT scan performed at the last followup revealed a significantly reduced mass.

\section{Discussion}

PPL is very rare, and its biological features, clinical presentation, prognostic markers, and treatment are not well defined. Although PPL has various clinical symptoms, they are nonspecific and contribute little to 


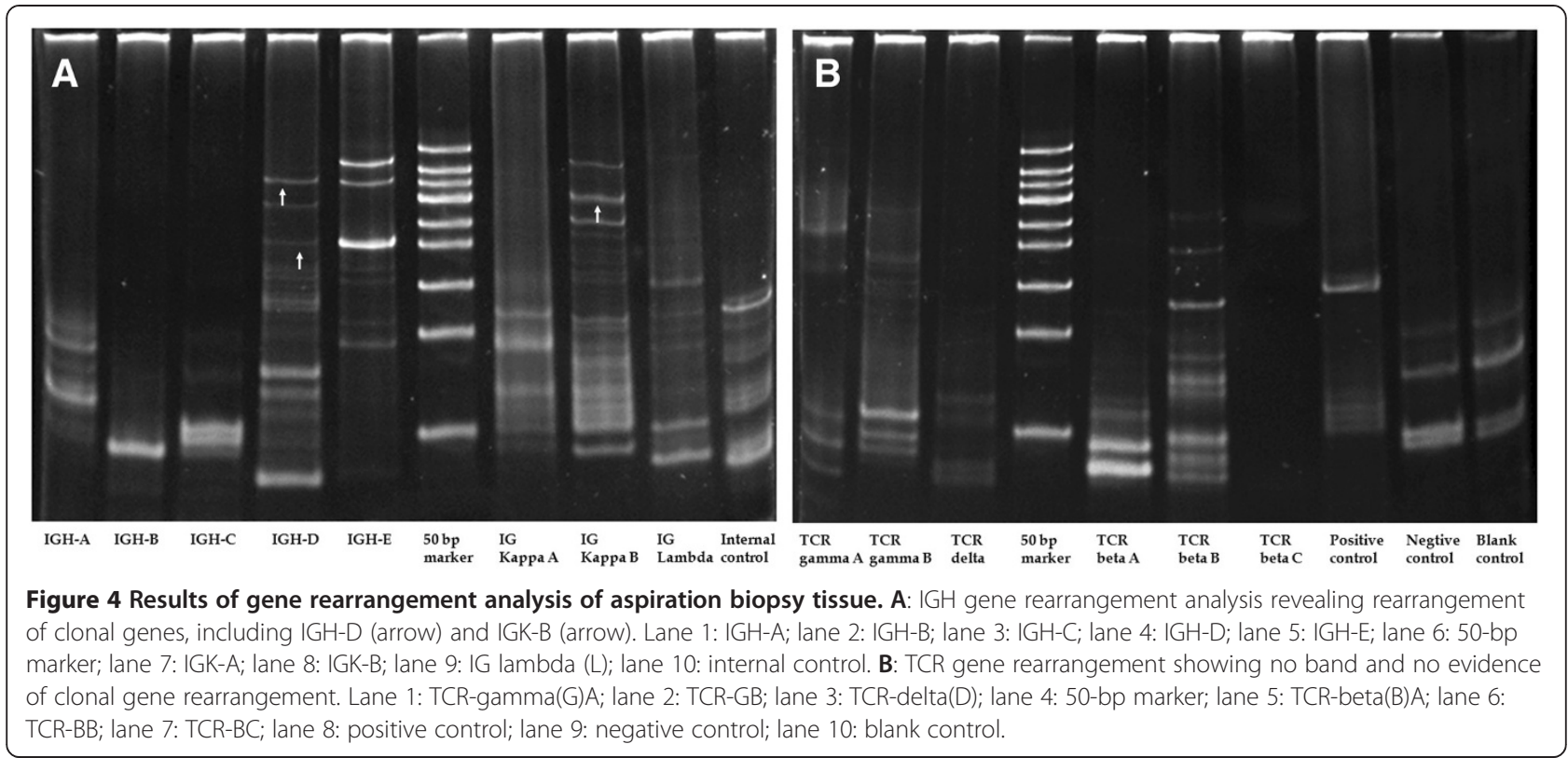

the diagnosis. Furthermore, $37.5-50 \%$ of patients are asymptomatic [2,7]. Moreover, the rate of constitutional symptoms and acute-phase reactants (sedimentation, C-reactive protein) are high in patients with PPL, which is also not specific to the diagnosis [8]. Thus, in addition to the pathological manifestations of bronchial mucosal biopsy and surgical biopsy, abnormal chest radiography and CT images may also be of value for diagnosis. Recently, increased numbers of disuse large B-cell lymphoma (DLBCL) cases with various manifestations have been reported, which could be misdiagnosed as TB [9] or lung cancer [10]. A long-term follow-up study of PPL-DLBCL, the largest known series thus far, noted strong homogeneity among the patients: low clinical risk, early stage, and no bulky tumor mass, normal lactic dehydrogenase and beta 2 microglobulin [11]. Yet, some cases also have unusual morphological features, where primary pulmonary B cell lymphoma might present as a necrotic mass or mediastinal type $[12,13]$.

The most common histopathological subtypes of PPL are mucosa-associated lymphoid tissue (MALT) lymphoma and diffuse large B cell lymphoma (DLBCL), which occurs only in $10 \%$ of cases $[14,15]$. In general, there is no clear classification of DLBCL encountered in pulmonary systems. In fact, PLL-DLBCL has been reported only in case reports $[9,10]$, most subtypes of them are centroblastic or immunoblastic variants, as elsewhere, which are the more common morphological variants of DLBCL $[1,11,16,17]$. In addition, some rare types of DLBCL, such as the anaplastic variant, were also reported [18]. Histopathologically, the case we presented here contained both large and small lymphoid cells, and abundant eosinophils were also found in the tumor tissue. Immunohistochemical staining revealed that the large lymphoid cells were B-cells (both CD20- and Pax5-positive) and small lymphoid cells were predominantly T-cells (CD3-positive) in nature. Our finding is obviously different from the studies $[11,13,19]$ in which immunophenotype of primary B cell lymphoma of the lung is commonly CD3-negative. Meanwhile, many CD68positive cells were also found, but there were only a few large CD30-positive and CD1 $\alpha$-positive cells in the tumor tissue. In addition, no any S100-positive and definite CD15positive cells were found. It means that large B-cells are mingled with abundant small T-cells and histiocytes. BIOMED-2 gene rearrangement analysis [6] of both the lung tissue and tumor cells confirmed that large B-cells are neoplastic and small $\mathrm{T}$-cells are reactive. Therefore, the diagnosis of this case is $\mathrm{T}$ - cell/histiocyte-rich large B cell lymphoma (THRLBCL), which is a special and rare subtype of DLBCL. Based on the typical cellular and immunohistochemical features of THRLBCL, which is composed of the dispersed large B-cells, predominant small T-cells and more histiocytes, it is not difficult to differentially diagnose it from other large B-cell lymphoma. If there is a difficult case, laboratory evaluation for EBV $[20,21]$ and immunohistochemical staining of OCT2 and BOB1 $[22,23]$ may be useful for the differential diagnosis of THRLBCL with other large B-cell lymphoma.

Upon histopathological examination, a marked increase of eosinophils in non-blood tissue could be diagnosed as tissue eosinophilia. However, eosinophilia refers to increased eosinophils $\left(>0.45 \times 10^{9} / \mathrm{L}\right)$ in the peripheral blood [24]. Peripheral blood and tissue eosinophilia may occur in many disorders, including allergic and 


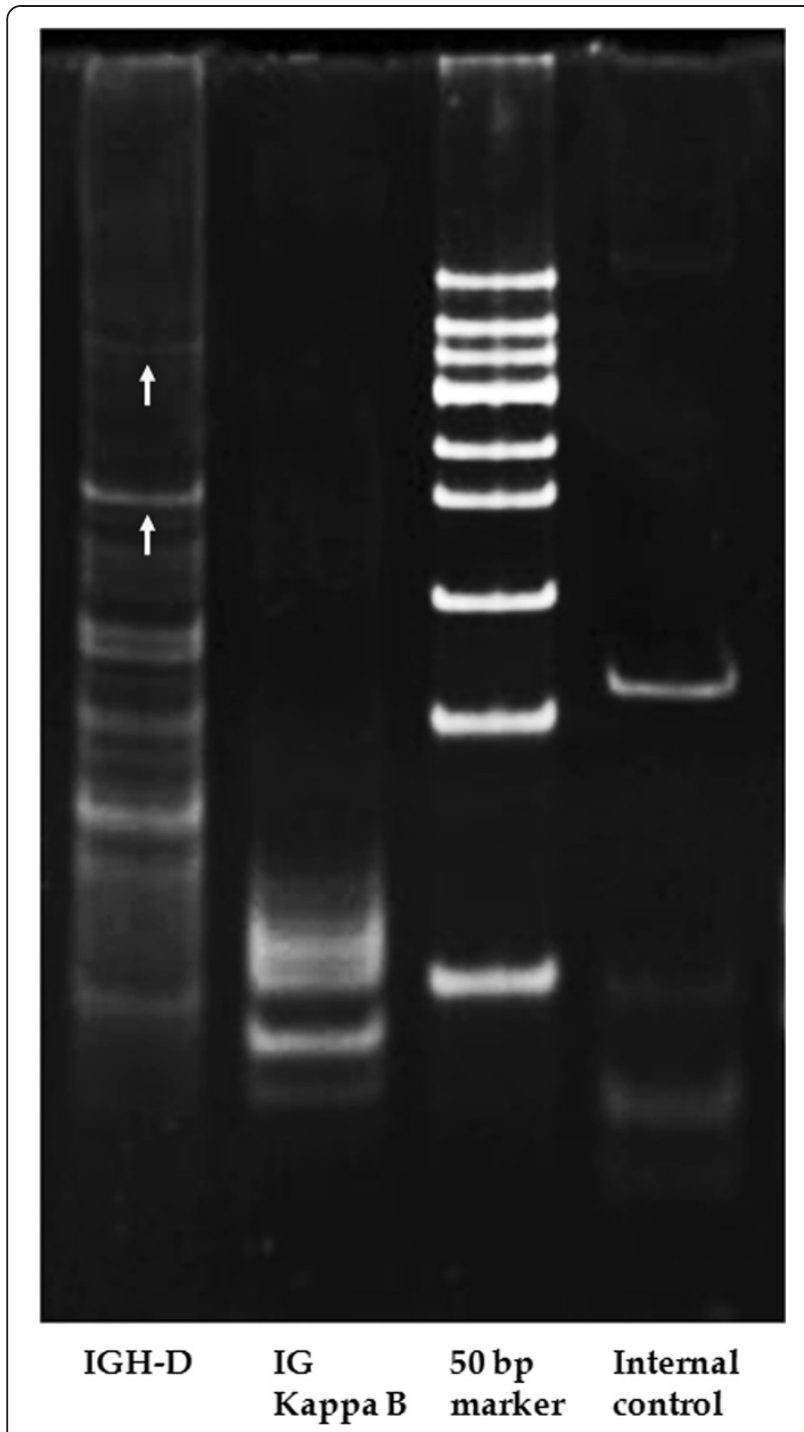

Figure $\mathbf{5}$ Results of gene rearrangement analysis of microdissection tissue. Laser capture microdissection of Pax5-positive large B lymphocytes confirm clonal IGH-D (arrow) gene rearrangement. Lane 1: IGH-D; lane 2: IGK-B; lane 3: 50-bp marker; lane 4: internal control.

hypersensitivity diseases, parasitic and viral infections, atopic reactions, immune complex disorders, connective tissue diseases, and malignant tumors. Both solid tumors and hematopoietic neoplasms are associated with eosinophilia. Eosinophilia and tissue eosinophilia are frequent findings in Hodgkin lymphoma [25] and are sometimes observed in patients with lymphoma, predominantly $\mathrm{T}$ cell lymphoma or occasionally anaplastic large cell lymphoma [26,27]. Historically, large B cell lymphoma with marked eosinophilia is rare, and only a few cases of mediastinal/thymic large $B$ cell lymphoma may present a few reactive infiltrating lymphocytes and eosinophils. Its clinical manifestation is an anterior mediastinal space-occupying lesion, usually accompanied by superior vena cava syndrome, and is easily misdiagnosed as Hodgkin lymphoma. To date, there are only a few reports on eosinophilia or tissue eosinophilia in B cell lymphoma, and all biopsy samples are obtained from lymph nodes [28-30]. In our case, however, it was primary pulmonary B cell lymphoma without evidence of nodal involvement, and all biopsy samples were obtained from lung tissue. The peripheral blood eosinophilic granulocyte count was in the normal range, and the bone marrow biopsy was normal. These findings did not support the diagnosis of eosinophilia. However, histopathological examination disclosed a lesion with marked eosinophil infiltration, some of which formed eosinophilic abscesses.

The differential diagnoses of eosinophil-rich lesions of the lung included eosinophilic granuloma, Hodgkin's lymphoma and parasitic or viral infections. In eosinophilic granuloma, there are a large number of characteristic Langerhans cells, which have typical nuclear grooves and showed both CD1 $\alpha$ and S100 diffuse positive staining. Furthermore, the gene rearrangement analysis can not reveal the clonal rearrangement of IGH genes. In classical Hodgkin's lymphoma, there are the typical Reed-Sternberg cells and their variants. In addition, abundant CD30- and CD15- positive cells may be also helpful for differential diagnosis with a large B-cell lymphoma. In parasitic or viral infections, it would yield polypides, eggs, or viral inclusion bodies under microscopy. Taken together, eosinophilic granuloma, Hodgkin's lymphoma and parasitic or viral infections could be excluded respectively.

Based on the cellular, immunohistochemical and molecular findings, we think that this is a unique case of primary pulmonary large B cell lymphoma with tissue eosinophilia.

The mechanism clarifying the relationship between tissue eosinophilia and B cell lymphoma remains unknown. Typically, it is believed that the eosinophilia is caused by the production of various cytokines, such as interleukin (IL)-5, IL-3, and granulocyte-macrophage colony-stimulating factor (GM-CSF) by B cell lymphoma cells or nonneoplastic $\mathrm{T}$ lymphocytes activated by B cell lymphoma cells [30,31]. In addition to the eosinophil chemotactic factors IL-3 and GM-CSF, IL-5 is a major soluble factor for mediating eosinophilia. It can be both a paracrine secretion from T cells [32] and an autonomous autocrine secretion from activated eosinophils [33,34]. Although the role of IL-4 in eosinophil recruitment is controversial [31], IL-4 is highly expressed by $\mathrm{T}$ cytotoxic 2 cells, with abundant background eosinophils, in $\mathrm{CD}^{+}$lymphomatoid papulosis [35]. Generally, these secreted cytokines may either act locally, recruiting eosinophils to the neoplasm, or have a systematic effect, increasing the number of eosinophils maturing and leaving the bone marrow [29]. Although the reason for tissue eosinophilia is as yet unknown, a large study of 1511 diagnostic biopsy 
specimens of patients has revealed that tissue eosinophilia correlated strongly with poor prognosis in nodular sclerosing Hodgkin's disease [36]. Similarly, the prognosis of large B cell lymphoma with tissue eosinophilia remains unknown for the rare of such cases and should also be considered.

There is evidence that MALT lymphoma of the lung is a very indolent disease with the potential for spontaneous regression [37] and that DLBCL of the lung may not portend as poor a prognosis as in other extranodal sites [11]. Prompt pathological diagnosis and initiation of therapy, including surgery, chemotherapy, radiotherapy, or combined treatments, are crucial to patient outcome. To date, the most effective therapy is anthracycline-containing chemotherapy, such as the CHOP or CHOP-like regimen, which is more commonly offered. The long-term follow-up study of Neri et al. showed that patients treated with $\mathrm{CHOP}$ achieved complete response (CR) $>80 \%$ and progressionfree survival (PFS) and overall survival (OS) $>5$ years [11]. Although the addition of rituximab to CHOP (R-CHOP) increased the CR rate, PFS, and OS in DLBCL $[38,39]$, especially in younger patients with low clinical risk, a recent study reported that there was no statistical difference in PPL-DLBCL following a retrospective comparison of patients who received $\mathrm{R}-\mathrm{CHOP}$ or $\mathrm{CHOP}$ alone [40].

\section{Conclusion}

In conclusion, this is the first reported case of T- cell/ histiocyte-rich large B cell lymphoma with tissue eosinophilia of the lung, which is difficult to diagnose and is easily confused with other diseases. Given the low incidence and favorable prognosis of PPL B cell lymphoma, a high index of suspicion must be maintained and the diagnosis should be performed with care using immunohistochemical staining; molecular analysis might aid the diagnosis, particularly in the case of small specimens such as that obtained by needle biopsy.

\section{Consent}

Written informed consent was obtained from the patient for publication of this Case Report and any accompanying images.

\footnotetext{
Abbreviations

PPL: Primary pulmonary lymphoma; IGH: Immunoglobulin heavy chain; $C T$ : Computed tomography; ESR: Erythrocyte sedimentation rate; BALF: Bronchoalveolar lavage fluid; TB: Mycobacterium tuberculosis; UV: Ultraviolet; FFPE: Formalin-fixed paraffin-embedded; TCR: T cell receptor; PCR: Polymerase chain reaction; CHOP: Cyclophosphamide, doxorubicin, vincristine, and prednisone; DLBCL: Disuse large B-cell lymphoma; MALT: Mucosa-associated lymphoid tissue; THRLBCL: T- cell/histiocyte-rich large B cell lymphoma; EBV: Epstein barr virus; IL: Interleukin; GM-CSF: Granulocyte-macrophage colony-stimulating factor; CR: Complete response; PFS: Progression-free survival; OS: Overall survival.
}

\section{Competing interests}

The authors declare that they have no competing interests.

\section{Authors' contributions}

$J Z$ selected the research topic, participated in the study, and wrote the manuscript. YMW carried out the immunoassays and wrote the manuscript. LG participated in the molecular genetic studies. GSH participated in the study design, contributed to the acquisition of clinical data and assisted the manuscript editing. All authors read and approved the final manuscript.

\section{Author details}

${ }^{1}$ The State Key Laboratory of Cancer Biology, Department of Pathology, Xijing Hospital, Fourth Military Medical University, Changle West Road \#169, Xi'an 710032, People's Republic of China. ²Department of Clinical Laboratory, The Affiliated Hospital of Lintong Sanatorium, Lanzhou Military Command, Qinling North Road, Xi'an 710600, People's Republic of China. ${ }^{3}$ The Helmholtz Sino-German Laboratory for Cancer Research, Department of Pathology, Tangdu Hospital, the Fourth Military Medical University, Xi'an 710038, People's Republic of China.

Received: 10 May 2014 Accepted: 20 September 2014

Published online: 02 October 2014

\section{References}

1. Cadranel J, Wislez M, Antoine M: Primary pulmonary lymphoma. Eur Respir J 2002, 20:750-762.

2. Ferraro P, Trastek VF, Adlakha H, Deschamps C, Allen MS, Pairolero PC: Primary non-Hodgkin's lymphoma of the lung. Ann Thorac Surg 2000, 69:993-997.

3. William J, Variakojis D, Yeldandi A, Raparia K: Lymphoproliferative neoplasms of the lung: a review. Arch Pathol Lab Med 2013, 137:382-391.

4. Kim JH, Lee SH, Park J, Kim HY, Lee SI, Park JO, Kim K, Kim WS, Jung CW, Park YS, Im YH, Kang WK, Lee MH, Park K, Han JH, Ko YH: Primary pulmonary non-Hodgkin's lymphoma. Jpn J Clin Oncol 2004, 34:510-514.

5. Radin Al: Primary pulmonary Hodgkin's disease. Cancer 1990, 65:550-563.

6. Liu H, Bench AJ, Bacon CM, Payne K, Huang Y, Scott MA, Erber WN, Grant JW, Du MQ: A practical strategy for the routine use of BIOMED-2 PCR assays for detection of B- and T-cell clonality in diagnostic haematopathology. Br J Haematol 2007, 138:31-43.

7. Poletti V, Romagna M, Gasponi A, Baruzzi G, Allen KA: Bronchoalveolar lavage in the diagnosis of low-grade, MALT type, B-cell lymphoma in the lung. Monaldi Arch Chest Dis 1995, 50:191-194.

8. Kocaturk Cl, Seyhan EC, Gunluoglu MZ, Urer N, Kaynak K, Dincer SI, Bedirhan MA: Primary pulmonary non-Hodgkin's lymphoma: ten cases with a review of the literature. Tuberk Toraks 2012, 60:246-253.

9. Srinivasan A, Ravikumar T, Andal A, Scott JX: Primary pulmonary diffuse large B-cell non-Hodgkin's lymphoma in a child. Indian J Chest Dis Allied Sci 2013, 55:225-227.

10. Wei S, Li X, Qiu X, Zhao H, Chen G, Chen J, Zhou Q: Primary lung lymphoma involving the superior vena cava. World J Surg Oncol 2012, 10:131.

11. Neri $N$, Jesus Nambo M, Aviles A: Diffuse large B-cell lymphoma primary of lung. Hematology 2011, 16:110-112.

12. Brown S, Horton J, Rosario D, Dorsey DA, Hetz S, King CS: High-grade primary pulmonary $B$ cell lymphoma presenting as a necrotic mass. Respir Care 2011, 56:871-873.

13. Chen G, Yim AP, Ma L, Gaulard P, Chan JK: Primary pulmonary large B-cell lymphoma-mediastinal type? Histopathology 2011, 58:324-326.

14. Chilosi M, Zinzani PL, Poletti V: Lymphoproliferative lung disorders. Semin Respir Crit Care Med 2005, 26:490-501.

15. Zinzani PL, Martelli M, Poletti V, Vitolo U, Gobbi PG, Chisesi T, Barosi G, Ferreri AJ, Marchetti M, Pimpinelli N, Tura S: Practice guidelines for the management of extranodal non-Hodgkin's lymphomas of adult non-immunodeficient patients. Part l: primary lung and mediastinal lymphomas. A project of the Italian Society of Hematology, the Italian Society of Experimental Hematology and the Italian Group for Bone Marrow Transplantation. Haematologica 2008, 93:1364-1371.

16. Li G, Hansmann ML, Zwingers T, Lennert K: Primary lymphomas of the lung: morphological, immunohistochemical and clinical features. Histopathology 1990, 16:519-531.

17. Wrobel T, Dzietczenia J, Prochorec-Sobieszek M, Mazur G, Piwkowski P: Primary pulmonary diffuse large B-cell lymphoma. Am J Hematol 2012, 87:107-108. 
18. Kos Z, Burns BF, Gomes MM, Sekhon HS: A rare case of anaplastic variant of diffuse large B-cell lymphoma presenting as a lung primary. Int J Surg Pathol 2014, 22:167-171.

19. $\mathrm{Yu} \mathrm{H}$, Chen $\mathrm{G}$, Zhang $\mathrm{R}$, Jin X: Primary intravascular large B-cell lymphoma of lung: a report of one case and review. Diagn Pathol 2012, 7:70.

20. Lim MS, Beaty M, Sorbara L, Cheng RZ, Pittaluga S, Raffeld M, Jaffe ES: T-cell/histiocyte-rich large B-cell lymphoma: a heterogeneous entity with derivation from germinal center B cells. Am J Surg Pathol 2002, 26:1458-1466.

21. Achten $R$, Verhoef $G$, Vanuytsel L, De Wolf-Peeters C: T-cell/histiocyte-rich large B-cell lymphoma: a distinct clinicopathologic entity. J Clin Oncol 2002, 20:1269-1277.

22. Tousseyn T, De Wolf-Peeters C: T cell/histiocyte-rich large B-cell lymphoma: an update on its biology and classification. Virchows Arch 2011, 459:557-563.

23. Carbone A, Gloghini A, Aiello A, Testi A, Cabras A: B-cell lymphomas with features intermediate between distinct pathologic entities. From pathogenesis to pathology. Hum Pathol 2010, 41:621-631.

24. Simon D, Simon HU: Eosinophilic disorders. J Allergy Clin Immunol 2007, 119:1291-1300. quiz 1301-1292.

25. Kumar R, Sidhu H, Mistry R, Shet T: Primary pulmonary Hodgkin's lymphoma: a rare pitfall in transthoracic fine needle aspiration cytology. Diagn Cytopathol 2008, 36:666-669.

26. Thielen C, Radermacher V, Trimeche M, Roufosse F, Goldman M, Boniver J, de Leval L: TARC and IL-5 expression correlates with tissue eosinophilia in peripheral T-cell lymphomas. Leuk Res 2008, 32:1431-1438.

27. Kong YY, Dai B, Kong JC, Lu HF, Shi DR: Neutrophil/eosinophil-rich type of primary cutaneous anaplastic large cell lymphoma: a clinicopathological, immunophenotypic and molecular study of nine cases. Histopathology 2009, 55:189-196

28. Watanabe K, Shinbo T, Kojima M, Naito M, Tanahashi N, Nara M: B-cell lymphoma associated with eosinophilia. Cancer 1989, 64:1682-1685.

29. Navarro-Roman L, Medeiros LJ, Kingma DW, Zarate-Osorno A, Nguyen V, Samoszuk M, Jaffe ES: Malignant lymphomas of B-cell lineage with marked tissue eosinophilia. A report of five cases. Am J Surg Pathol 1994, 18:347-356.

30. Shiraishi J, Nakagawa Y, Kurata M, Yamamoto K, Abe Y, Toyoda Y, Suzuki K, Kitagawa M, Takemura T: Follicular lymphoma with marked infiltration of eosinophils. Pathol Int 2008, 58:701-705.

31. Simon HU, Yousefi S, Schranz C, Schapowal A, Bachert C, Blaser K: Direct demonstration of delayed eosinophil apoptosis as a mechanism causing tissue eosinophilia. J Immuno/ 1997, 158:3902-3908.

32. Hirashima M, Ueno M, Saita N, Takamura S, Watanabe K, Tsurufuji S, Adachi $\mathrm{M}$ : Induction of an eosinophil chemotactic factor production from T lymphocytes by a B cell lymphoma line. Immunol Lett 1993, 36:273-281.

33. Desreumaux P, Janin A, Colombel JF, Prin L, Plumas J, Emilie D, Torpier G, Capron A, Capron M: Interleukin 5 messenger RNA expression by eosinophils in the intestinal mucosa of patients with coeliac disease. J Exp Med 1992, 175:293-296.

34. Rapanotti MC, Caruso R, Bernardini S, Coletti V, Lo-Coco F, De Rossi G: Idiopathic hypereosinophilic syndrome: a case evolving in B-lymphoblastic lymphoma. Leuk Res 2005, 29:975-979.

35. Slone SP, Martin AW, Wellhausen SR, Woods DR, Malone JC, Lear SC, Laber DA: IL-4 production by CD8+ lymphomatoid papulosis, type $C$, attracts background eosinophils. J Cutan Pathol 2008, 35(Suppl 1):38-45.

36. von Wasielewski R, Seth S, Franklin J, Fischer R, Hubner K, Hansmann ML, Diehl V, Georgii A: Tissue eosinophilia correlates strongly with poor prognosis in nodular sclerosing Hodgkin's disease, allowing for known prognostic factors. Blood 2000, 95:1207-1213.

37. Troch M, Streubel B, Petkov V, Turetschek K, Chott A, Raderer M: Does MALT lymphoma of the lung require immediate treatment? An analysis of 11 untreated cases with long-term follow-up. Anticancer Res 2007, 27:3633-3637

38. Coiffier B, Thieblemont C, Van Den Neste E, Lepeu G, Plantier I, Castaigne S, Lefort S, Marit G, Macro M, Sebban C, Belhadj K, Bordessoule D, Ferme C, Tilly H: Long-term outcome of patients in the LNH-98.5 trial, the first randomized study comparing rituximab-CHOP to standard $\mathrm{CHOP}$ chemotherapy in DLBCL patients: a study by the Groupe d'Etudes des Lymphomes de l'Adulte. Blood 2010, 116:2040-2045.

39. Fu K, Weisenburger DD, Choi WW, Perry KD, Smith LM, Shi X, Hans CP, Greiner TC, Bierman PJ, Bociek RG, Armitage JO, Chan WC, Vose JM:
Addition of rituximab to standard chemotherapy improves the survival of both the germinal center B-cell-like and non-germinal center B-cell-like subtypes of diffuse large B-cell lymphoma. J Clin Oncol 2008, 26:4587-4594.

40. Aviles A, Nambo MJ, Huerta-Guzman J, Silva L, Neri N: Rituximab in the treatment of diffuse large B-cell lymphoma primary of the lung. Hematology 2013, 18:81-84

doi:10.1186/s13000-014-0188-6

Cite this article as: Zhu et al:: Diagnosis of primary pulmonary T- cell/ histiocyte-rich large B cell lymphoma with tissue eosinophilia via clinicopathological observation and molecular assay. Diagnostic Pathology 2014 9:188.

\section{Submit your next manuscript to BioMed Central and take full advantage of:}

- Convenient online submission

- Thorough peer review

- No space constraints or color figure charges

- Immediate publication on acceptance

- Inclusion in PubMed, CAS, Scopus and Google Scholar

- Research which is freely available for redistribution 